\title{
The Master of Psychopharmacology: an inspiration for future generations - Donald F. Klein (1928-2019)
}

\author{
Antonio E. Nardi, ${ }^{1}$ iD Rafael C. Freire, ${ }^{1,2}$ iD Jeffrey P. Kahn ${ }^{3}$ iD
}

${ }^{1}$ Laboratório de Pânico e Respiração, Instituto de Psiquiatria, Universidade Federal do Rio de Janeiro (UFRJ), Rio de Janeiro, RJ, Brazil.

${ }^{2}$ Department of Psychiatry, Queen's University, Kingston, Canada. ${ }^{3}$ Department of Psychiatry, Weill Cornell Medical College, New York, USA.

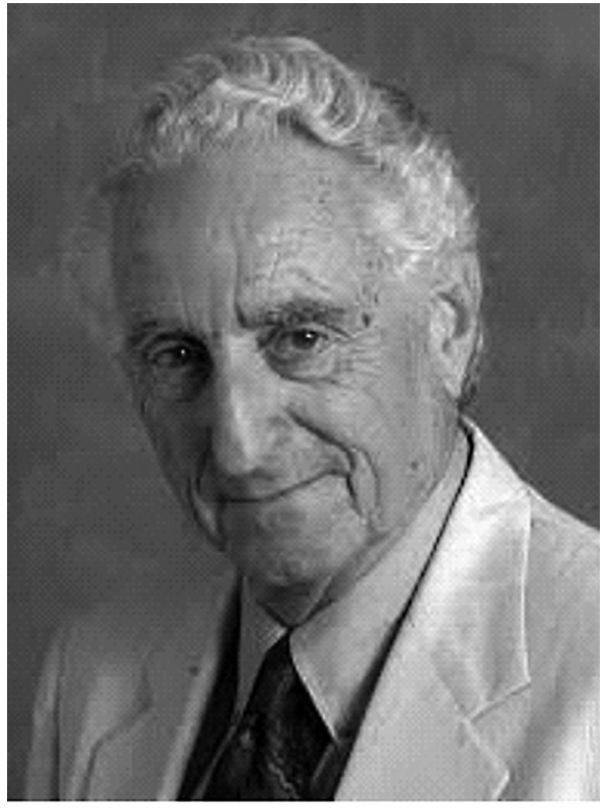

Professor Donald F. Klein

September 4, 1928 - August 7, 2019

A master of clinical psychopharmacology, Professor Donald Franklin Klein - or Don Klein to his close admirers - was born in New York City on September 4, 1928. He grew up in the Bronx and earned a bachelor's degree from Colby College in Maine at the age of 18 , in 1947. Before being admitted to medical school, he was an undergraduate student in the biochemistry and physiology program at New York University. He earned his M.D. from the State University of New York (SUNY) Downstate in 1952. Professor Klein passed away on August 7, 2019 in Manhattan. He was married twice; first to Estelle Manette, and later to scientist and clinical psychologist Rachel Kravetz. She survives him, as do five daughters and eight grandchildren. ${ }^{1}$ Professor Klein was an overenergetic researcher in clinical psychopharmacology and psychopathology, and published in such varied areas of psychiatry as panic disorder, depression, mood disorders, childhood anxiety, schizophrenia, and in related

Correspondence: Antonio Egidio Nardi

E-mail: antonioenardi@gmail.com areas of methodology and ethics. Among publications in prestigious journals such as Science, JAMA, The Lancet, The American Journal of Psychiatry and JAMA Psychiatry, Professor Klein published an update article ${ }^{2}$ and two editorials $^{3,4}$ in the Brazilian Journal of Psychiatry.

After graduating from medical school, Donald Klein completed a Public Health Service internship, then a firstyear residency at the Creedmoor Psychiatric Center in Queens. He then returned to the Public Health Service for a stint at the Narcotic Farm in Lexington, Kentucky. There he worked under Abraham Wikler, who was exploring the relationship between physiology, neurology, and addiction; Professor Klein conducted several drug trials. After 2 years, he returned to Creedmoor. In the late 1950s, he joined Zucker Hillside Hospital in Queens, known as a hotbed of psychiatric research. There, working under Max Fink, Professor Klein became increasingly interested in psychopharmacology, collecting data on the effects of drugs on various conditions. He noticed that, when patients with a peculiar kind of anxiety attack that included agoraphobia were given imipramine, their panic attacks subsided. He was a leading proponent of using "pharmacological dissection" as a tool to subtype anxiety, depressive, and other psychiatric disorders. A detailed account of this history is included in his foreword to the book Panic Disorder: Neurobiological and Treatment Aspects. ${ }^{5}$

Still in the 1950s, Dr. Klein, a psychiatrist with a robust background in neurobiology, brought new rigor to the study of whether some psychiatric problems might have a biological basis that could be efficaciously treated with medications. At the time, psychotherapy was the go-to tool for treating depression and other mental problems, and the use of medications was somewhat haphazard. In other words, he played a central role in bringing psychiatry closer to other medical specialties. Emphasizing the importance of judicious scientific research, he utilized clinical observation, patient self-reports, assessment of pharmacological response, laboratory testing, and statistical analysis. His work helped refine or even create definitions for several psychiatric disorders, and, as a result, he helped establish the legitimacy of psychopharmacology as an adjunct to psychotherapy. This rigorous inquiry continued when Dr. Klein moved to 
Columbia University's College of Physicians \& Surgeons in 1976, becoming Director of Research and chief of the Division of Therapeutics at the New York State Psychiatric Institute. He studied depression, panic disorder, the relation between childhood anxiety and problems in adulthood, and much more. He traveled widely, gave lectures, and was an example for psychiatrists the world over. He visited Brazil many times, including unforgettable lectures as in the Brazilian Congress of Psychiatry in 2016, among others.

He was awarded an honorary Doctor of Science degree from the SUNY Downstate Medical Center and was Professor of Emeritus Psychiatry at Columbia University from 2007. Since 2009, he was a Research Professor at the NYU Langone Medical Center Department of Child and Adolescent Psychiatry. Among his previous activities, he participated in the DSM-III Task Force from 19791981; was Senior Science Advisor at the Alcohol, Drug Abuse, and Mental Health Administration (now SAMHSA) in 1989-1990; Professor of Psychiatry at Columbia University School of Medicine, New York State Psychiatric Institute, from 1978-2007; and, concurrently, Research Director and Director of Therapeutics at the New York State Psychiatric Institute from 1976-2007. In 1980, he simultaneously chaired the American Psychopathological Association and the Psychiatric Research Society, and in 1981, was President of the American College of Neuropsychopharmacology. Among his outstanding scientific papers are: "Psychiatric reaction patterns to imipramine,"6 reporting his discovery of panic attack blockade with imipramine in 1962, formulating concepts of panic disorder and agoraphobia, and addressing challenges in the physiology of panic disorder and separation anxiety ${ }^{6,7}$; "False suffocation alarms, spontaneous panics, and related conditions: an integrative hypothesis,"7 where he laid out the false suffocation alarm theory of panic disorder; and "Panic, suffocation false alarms, separation anxiety and endogenous opioids,"8 a review of the false suffocation alarm theory which included the role of endogenous opioids. He established the main features of atypical depression ${ }^{9}$ and demonstrated differential responses to treatment with imipramine, electroconvulsive therapy, and monoamine oxidase inhibitors. ${ }^{10}$
He authored more than 500 peer-reviewed journal articles and more than 100 book chapters on the diagnosis and drug treatment of psychiatric disorders, received several major awards from various scientific societies worldwide, and, most importantly, was a mentor, teacher, and advisor to countless psychiatrists - ourselves among them.

Professor Donald Klein was a special person: unfailingly kind to everyone, slightly shy, but confident in his scientific and clinical claims. As with all great scientists, his vision was expansive, and his curiosity endless. A remarkable example for all of us trying to follow his teachings. His work and memory will be with us forever, and will inspire future generations as they look beyond. His are the shoulders they will stand upon.

Thank you, Don.

\section{Disclosure}

The authors report no conflicts of interest.

\section{References}

1 Genzlinger N. Donald Klein, who expanded the psychiatric toolbox, dies at 90 [Internet]. The New York Times. 2019 Aug 16 [cited 2019]. www.nytimes.com/2019/08/16/science/donald-klein-dead.html

2 Klein DF, Glick ID. Industry withdrawal from psychiatric medication development. Braz J Psychiatry. 2014;36:259-61.

3 Klein DF. Panic developments. Braz J Psychiatry. 2012;34 Suppl 1: S1-2.

4 Klein DF. Difficulties in panic studies. Braz J Psychiatry. 2013;35: 215-6.

5 Nardi AE, Freire RC. Panic disorder: neurobiological and treatment aspects. In: Nardi AE, Freire RCR, editors. Cham: Springer International; 2016. p. i-xxi.

6 Klein DF, Fink M. Psychiatric reaction patterns to imipramine. Am J Psychiatry. 1962;119:432-8.

7 Klein DF. False suffocation alarms, spontaneous panics, and related conditions. An integrative hypothesis. Arch Gen Psychiatry. 1993;50: 306-17.

8 Preter M, Klein DF. Panic, suffocation false alarms, separation anxiety and endogenous opioids. Prog Neuropsychopharmacol Biol Psychiatry. 2008;32:603-12.

9 Klein DF. Endogenomorphic depression. A conceptual and terminological revision. Arch Gen Psychiatry. 1974;31:447-54.

10 Klein DF. Indications for specific treatments of depressions. Psychopharmacol Bull. 1975;11:3-13. 